Hutsul, N., Rykhal, V., Okopnyy, A., \& Vovk, I. (2020). Comparative Analysis of the Kickboxers' Impact Techniques Indicators at the Preliminary Basic Training Stage Taking Into Account the Weight Categories. Teoriâ ta Metodika Fizičnogo Vihovannâ, 20(3), 182-190. https://doi.org/10.17309/tmfv.2020.3.08

ISSN 1993-7989 (print). ISSN 1993-7997 (online)

\title{
COMPARATIVE ANALYSIS OF THE KICKBOXERS' IMPACT TECHNIQUES INDICATORS AT THE PRELIMINARY BASIC TRAINING STAGE TAKING INTO ACCOUNT THE WEIGHT CATEGORIES
}

\author{
Natalia Hutsul ${ }^{1 \mathrm{ABCD}}$, Volodymyr Rykhal ${ }^{2 \mathrm{ABCD}}$, Andriy Okopnyy ${ }^{2 \mathrm{ABCD}}$, Igor Vovk ${ }^{3 \mathrm{ABCD}}$ \\ ${ }^{1}$ Ukrainian Academy of Printing, \\ ${ }^{2}$ Lviv State University of Physical Culture named after Ivan Boberskyi, \\ ${ }^{3}$ Lviv National Agrarian University \\ Authors' Contribution: A - Study design; B - Data collection; C - Statistical analysis; D - Manuscript Preparation; E - Funds Collection
}

Corresponding Author: Natalia Hutsul, e-mail: umbanathalie88@gmail.com

Accepted for Publication: September 20, 2020

Published: September 25, 2020

DOI: 10.17309/tmfv.2020.3.08

\begin{abstract}
The objective of the study is to conduct a comparative analysis of the kickboxers experimental and control groups' performance.

Materials and methods. The pedagogical study involved 60 kickboxers who were at the stage of preliminary basic training. There were formed two homogeneous groups. The experimental group consisted of 30 people in three categories: I (67 kg), II (70 kg), III (74 kg). There were 10 people in each category. The control group also consisted of 30 people in the same three categories: I $(67 \mathrm{~kg})$, II $(70 \mathrm{~kg})$, III $(74 \mathrm{~kg})$. There were also 10 people in each category.

Results. The ratio of impact techniques quantitative indicators between the control and experimental groups determines the effectiveness of kick-boxers' impact techniques at the stage of preliminary basic training, taking into account the weight categories, where the experimental group significantly exceeded $(p \leq 0.05)$ the control group by all indicators. Conclusions. The study of existing research has revealed that the analysis of motor performance techniques of kickboxers can be a component of training to improve the efficiency of the training process and the effectiveness of competitive activities.

The analysis of the special literature allowed to determine the most frequently performed percussion techniques in oriental martial arts.

The results obtained after the experiment indicate that the indicators of technical motor actions of kickboxers in the experimental group are significantly higher $(p \leq 0.05)$ than in the control group. A detailed analysis of the technique of percussion among kickboxers allowed to establish the difference in technical training between athletes of the experimental and control groups, taking into account weight categories during the performance of eight strokes for the first category $(67 \mathrm{~kg}$ ) were in the range of $14.7-36.3 \%$ (in the second category, $70 \mathrm{~kg}$ ) - 15.0-51.2\% and III category $(74 \mathrm{~kg})-15.3-66.6 \%$ in favor of the experimental group.

Keywords: technique, kicks, kickboxers, weight classes, preliminary basic training stage.
\end{abstract}

\section{Introduction}

Kickboxing is one of the most intensively studied martial arts nowadays. This is evidenced by fundamental papers by Yaremko (2001), Skyrta, Horbenko, Khatsaiuk, and Piniker (2014). As far as it is known, modern kickboxing battles are full of considerable workload, mental, physical and emotional stress. And as a result there arises the role of technical readiness and, accordingly, training of kickboxers' technique.

(C) Natalia Hutsul, Volodymyr Rykha, Andriy Okopnyy, Igor Vovk, 2020 .
Traditional methods of the kickboxers' technical skills improving are aimed at working out the basic techniques, as well as taking into account the individual features of athletes and kinematic features of their attacking actions.

Based on the method of competitive activity analysis (by the Frolov's Method, which allows determining the level of technical and tactical readiness of athletes, due to obtaining quantitative and qualitative characteristics of the battle. Kickboxing racing activities were analyzed by Buse, and Santana (2008), Yaremko (2001) and more others.

In sports theory, there are several approaches to defining the technique of sport. Platonov (1997) describes sports 
equipment as a set of techniques and actions that provide the most effective solution to motor problems, due to the specificity of a particular sport, type of competition.

One of the important types of kickboxers training is the key to improving their technical skills. It was studied by Romanov (2003), Skyrta and Khatsaiuk (2014). Several other authors have spoken on this issue, for example, Yaremko (2001), Hutsul, Skyrta, and Rykhal (2019). High-level kickboxers (ISUs and ISMCs) have difficulty in technical training. More details about these issues are considered by such authors as: Booth (2006), Kiatbusaba (2013), Stewart (2011).

The problem of improving the technical skill of athletes in martial arts recently considered the following experts: Ostianov and Haidamak (2001), Bakulev, Nazarenko, and Momot (2007), Skyrta, Horbenko, Khatsaiuk, and Piniker (2014).

The high level of modern kickboxing requires an effective solution to the main problems of formation and improvement of the theory and methodology of the educational and teaching process. Effective technical actions in competitive activities were studied in the papers of Pat O'Keeffe (2002), Ouergui, Hssin, Haddad, Franchini, Behm, Wong, Gmada, and Bouhlel (2014), Savchyn (2016), Pityn, Okopnyy, Tyravska, Hutsul, and Ilnytsky (2017).

Studies of various aspects of kickboxer training confirm the high level of dependence on the results of competitive activity on the level of technical training. The key aspect is to increase the effectiveness of the impact. This methodical approach to the analysis of technical skill in martial arts was used by Sayenko (2010), Gerasimov, (2014), Hutsul and Rykhal (2020).

As it is known, the bases of the physical exercises technique are movements, the totality of which is part of human motor skills. It can only be described by technical specifications. The issue of kickboxing technical training is covered in the papers of Skyrta and Khatsaiuk (2014). A number of authors claimed the rational technology performance of certain martial arts types, like Sayenko (2010), Prystupa, Okopnyy, Hutsul, Khimenes, Kotelnyk, Hryb, and Pityn (2019).

Improvements in technical skill are justified by many experts on various sports. Kickboxing is not an exception, because to win in a minimum amount of time in a competition is one of the leading single-player challenges. For the effective implementation of this task, it is necessary to carry out at the expense of a high level of technical skill. That means the most rational structure of their performance during the battle. The analysis of impact techniques remains poorly understood in kickboxing during the pre-basic weight training stage.

The objective of the study is to conduct a comparative analysis of the kickboxers experimental and control groups' performance, taking into account the weight categories.

\section{Materials and methods}

\section{Study participants}

Sixty kickboxers who were at the stage of preliminary basic training participated in the pedagogical study. Two homogeneous groups were created. The experimental group consisted of 30 people in three categories: I (67 kg), II (70 kg), III $(74 \mathrm{~kg})$. There were 10 people in each category. The control group also consisted of 30 people in the same three catego- ries: I (67 kg), II (70 kg), III (74 kg). There were also 10 people in each category.

\section{Study organizing}

The indexes of the kickboxers impact technhniques were recorded by a special equipment. It was created by professor M.P. Savchyn (2003, Lviv). This is a specialized Spuderg impact dynamometer. This digital instrument allows you to continuously record various parameters of impact techniques. Among them there is the force of each stroke, the time intervals between strokes, the gradient of the efficiency of the stroke by the Savchyn's method (2003). The rapid acquisition of an indicator set provides an opportunity to monitor the technique during the strike and, if necessary, to adjust the training process. It works thanks to electronic instrumentation and chronodynamometry techniques. This technique has been tested in kickboxing, karate, and more other martial arts.

The athletes of the experimental group ( 30 people of 10 in each category, I (67 kg), II (70 kg), and III (74 kg) were at the stage of preliminary basic training. They were trained by the signature program to improve their technical skills. The athletes improved the basic technique, combat technique (attack-counterattack-defense), tactical techniques, psychological techniques, etc. However, the main tools in competitive activity are impact techniques. The study of the kickboxers technique due to weight categories is possible under the conditions of determining the most frequently performed impact techniques. They have been identified in competitive activities. So, the analysis of battles allowed us to select the following: arm punch (straight right, left side and bottom right), knee strike (bottom right), foot kick (straight right and straight left) and shin kick (right side to the head and right side to the thigh). Kickboxers were tested at the Typhoon sports complex. According to the training method, kickboxers were to perform in a competitional mode, showing their ten strongest separate strokes from above at a sound signal. To perform the kicks, the kickboxer was tested mid-range by a torque bag, maintained by an assistant, and sounded a conditioned punch. The best result, out of ten blows, was put in the record. To avoid deterioration in performance, as well as to maintain efficiency and maintain competitive testing conditions after ten strokes, the tested athlete was provided rest and substituted by another.

\section{Statistical analysis}

The processing of the test results was performed using mathematical statistics methods with the calculation of the Mann-Whitney probability difference $(p \leq 0.05)$.

\section{Results}

According to the impact technique, there were recorded quantitative indicators of the strokes effectiveness. The experimental group achieved a reliable indicator at $p \leq 0.05$ (Tables 1-3).

The study of the impact techniques gave reason to consider the difference between effectiveness of the standard ISKA program and the experimental group program, which trained by the signature program of improving technical 
Table 1. The ratio of the impact of kickboxers of the first category $(67 \mathrm{~kg})$ of the control and experimental groups $(\mathrm{M} \pm \mathrm{m})$

\begin{tabular}{|c|c|c|c|c|}
\hline Indicator & Execution of blows & $\begin{array}{c}\text { I }(67 \mathrm{~kg})(\mathrm{CG}) \\
(\mathrm{n}=10)\end{array}$ & $\begin{array}{c}\text { I }(67 \mathrm{~kg})(\mathrm{EG}) \\
\quad(\mathrm{n}=10)\end{array}$ & $\mathbf{P}$ \\
\hline \multirow{8}{*}{$\underset{\hat{0}}{\stackrel{0}{3}}$} & arm punch (SR)) & $0,44 \pm 0.05$ & $0,51 \pm 0,09$ & $\mathrm{p} \leq 0.05$ \\
\hline & arm punch (LS) & $0,41 \pm 0,03$ & $0,57 \pm 0,12$ & $\mathrm{p} \leq 0.05$ \\
\hline & arm punch (BR) & $0,44 \pm 0,04$ & $0,53 \pm 0,10$ & $\mathrm{p} \leq 0.05$ \\
\hline & knee strike (BR) & $0,47 \pm 0,06$ & $0,61 \pm 0,14$ & $\mathrm{p} \leq 0.05$ \\
\hline & foot kick (SR) & $0,49 \pm 0,08$ & $0,67 \pm 0,16$ & $\mathrm{p} \leq 0.05$ \\
\hline & foot kick (SL) & $0,45 \pm 0,03$ & $0,65 \pm 0,15$ & $\mathrm{p} \leq 0.05$ \\
\hline & foot kick (RSh) & $0,35 \pm 0,02$ & $0,49 \pm 0,08$ & $\mathrm{p} \leq 0.05$ \\
\hline & foot kick (RSt) & $0,61 \pm 0,014$ & $0,79 \pm 0,18$ & $\mathrm{p} \leq 0.05$ \\
\hline
\end{tabular}

Note: CG - control group; EG - experimental group

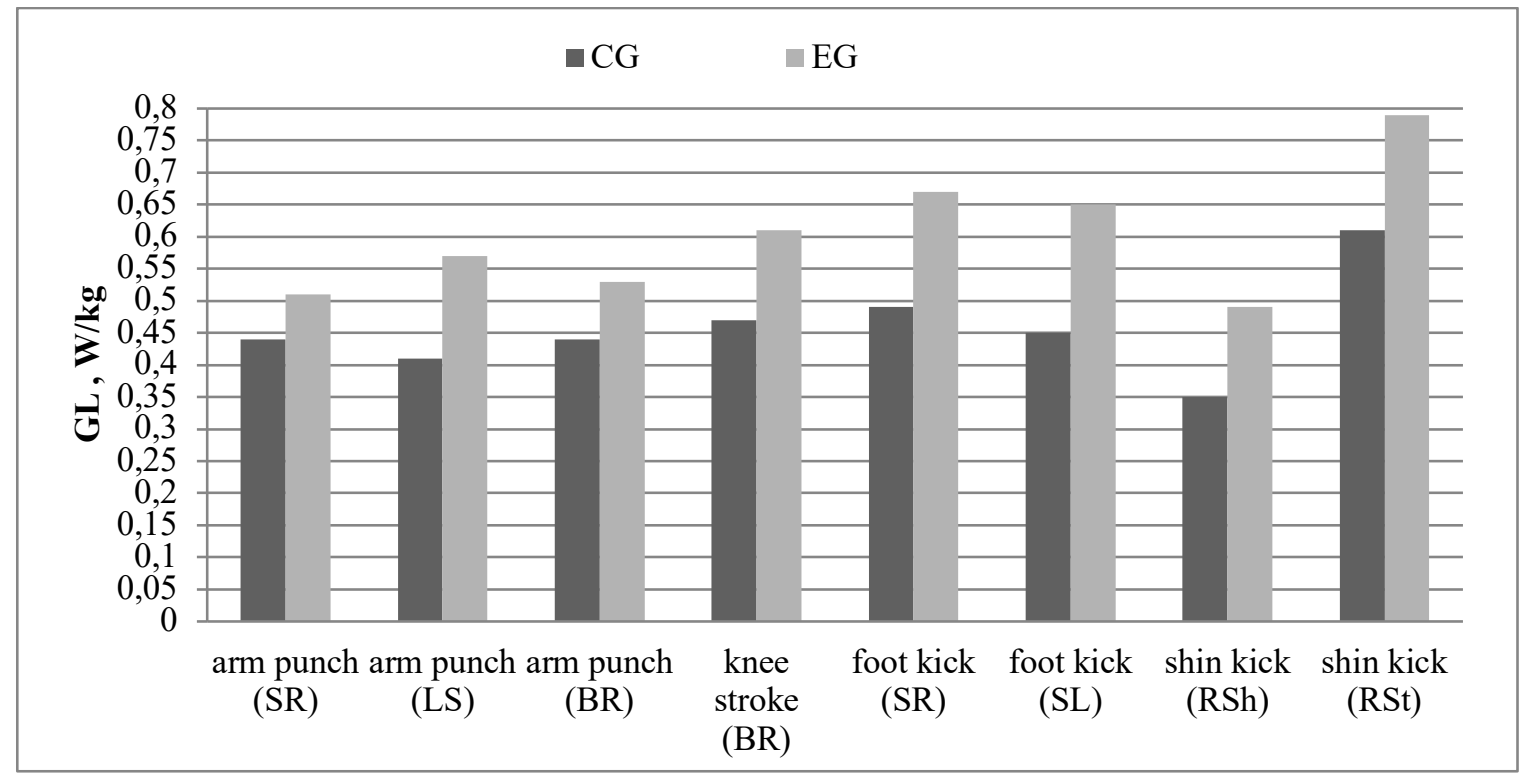

Fig. 1. The impact techniques of the kickboxers of the first category (67 kg): SR - straight right; LS - left side; BR bottom right; SR - straight right; SL - straight left; RSh - right side to the head; RSt - right side to the thigh.

kickboxers technique, taking into account weight categories. According to the ratios of quantitative indicators of impact techniques between groups (control and experimental) the effectiveness of technical actions of kickboxers at the stage of preliminary basic training, taking into account, can be determined. The weight categories had some differences. Judging by the impact techniques of the kickboxers of the first category (67 kg), the experimental group significantly exceeded $(p \leq 0.05)$ the control group by all indicators.

The indicator of arm punch (straight right) is higher on $14.7 \%$, to the left $-32.6 \%(p \leq 0.05)$. Punching below, the indicator is higher as well as the previous one $-18.5 \%$ at $(p \leq 0.05)$.

On the other index, knee strikes (bottom-right) were also at a significant level and were higher $-25.9 \%$ at $(p \leq 0.05)$.

Another trend in foot strikes was the same as for previous indicators, where the SR was higher $-31.0 \%$ at $(p \leq 0.05)$ and the SL $-36.3 \%$ at $(p \leq 0.05)$.

The last indicator was also higher for the expiremental group, but it was low compared to other. The kick (right side to the head) is higher $-33,3 \%$ at $(p \leq 0.05)$ and the one to the thigh $-25,7 \%$ at $(p \leq 0.05)$.

The analysis of kickboxers' impact techniques at the prebasic training stage, taking into account the weight categories for athletes of the second category $(70 \mathrm{~kg}$ ) had some differences. According to the ratio of indicators between the control and the experimental group, the reliability was in favor of the second one at $(p \leq 0.05)$.

In the right-handed punch, the figure is significantly higher $-18.1 \%$ at $(p \leq 0.05)$, in the side-left punch $-37.5 \%$ at $(p \leq 0.05)$ and in the bottom right $-15.0 \%$ at $(p \leq 0.05)$.

The figure on the right knee bottom stroke was also higher for the experimental group (35.5\% at $(p \leq 0.05))$.

In terms of impact, the foot was also statistically significant for the experimental group compared to the control group. For the straight right stroke it was $36.6 \%$ at $(p \leq 0.05)$ and for the straight left $-38.5 \%$ at $(p \leq 0.05)$. The index increased for both feet.

The last shin stroke right to the head was higher by $51.2 \%$ at $(p \leq 0.05)$ and the side right to the thigh at $19.8 \%$ at $(p \leq 0.05)$. 
Hutsul, N., Rykhal, V., Okopnyy, A., \& Vovk, I. (2020). Comparative Analysis of the Kickboxers' Impact Techniques Indicators at the Preliminary Basic Training Stage Taking Into Account the Weight Categories

Table 2. The ratio of impact indicators of kickboxers of the second category (70 kg) of the control and experimental groups $(\mathrm{M} \pm \mathrm{m})$

\begin{tabular}{|c|c|c|c|c|}
\hline Indicator & Execution of blows & $\begin{array}{c}\text { II }(70 \mathrm{~kg})(\mathrm{CG}) \\
\quad(\mathrm{n}=10)\end{array}$ & $\begin{array}{c}\text { II } \begin{array}{c}(70 \mathrm{~kg})(\mathrm{EG}) \\
(\mathrm{n}=10)\end{array} \\
\end{array}$ & $\mathbf{P}$ \\
\hline \multirow{8}{*}{$\frac{\sum_{0}^{\infty}}{3}$} & arm punch (SR)) & $0,45 \pm 0.05$ & $0,54 \pm 0,08$ & $\mathrm{p} \leq 0.05$ \\
\hline & arm punch (LS) & $0,39 \pm 0,03$ & $0,58 \pm 0,16$ & $\mathrm{p} \leq 0.05$ \\
\hline & arm punch (BR) & $0,43 \pm 0,04$ & $0,50 \pm 0,08$ & $\mathrm{p} \leq 0.05$ \\
\hline & knee strike (BR) & $0,44 \pm 0,06$ & $0,63 \pm 0,12$ & $\mathrm{p} \leq 0.05$ \\
\hline & foot kick (SR) & $0,50 \pm 0,11$ & $0,71 \pm 0,17$ & $\mathrm{p} \leq 0.05$ \\
\hline & foot kick (SL) & $0,46 \pm 0,03$ & $0,68 \pm 0,16$ & $\mathrm{p} \leq 0.05$ \\
\hline & foot kick (RSh) & $0,29 \pm 0,02$ & $0,49 \pm 0,08$ & $\mathrm{p} \leq 0.05$ \\
\hline & foot kick (RSt) & $0,50 \pm 0,08$ & $0,61 \pm 0,11$ & $\mathrm{p} \leq 0.05$ \\
\hline
\end{tabular}

Note: CG - control group; EG - experimental group

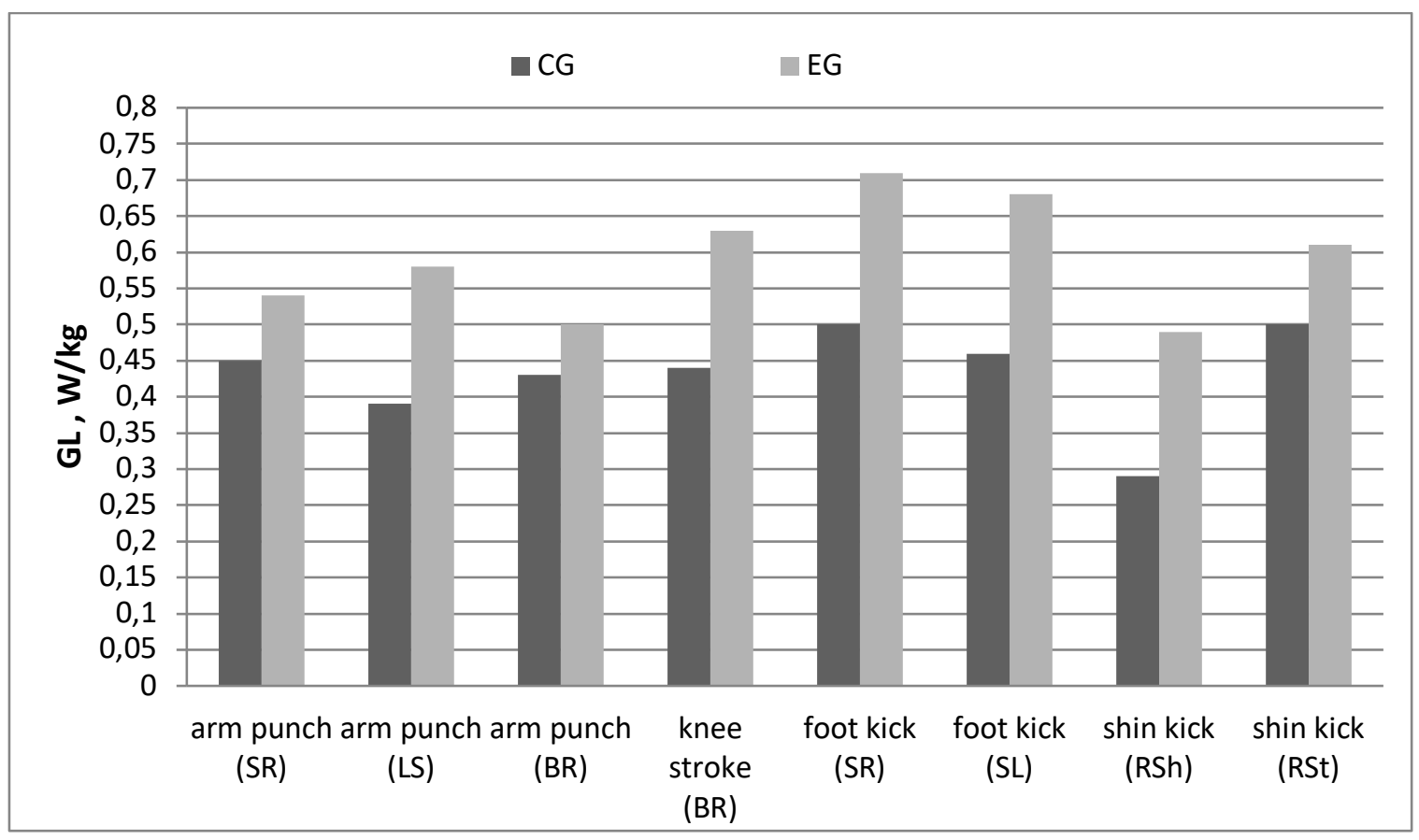

Fig. 2. The impact techniques of the kickboxers of the second category $(70 \mathrm{~kg})$ : SR - straight right; LS - left side; BR bottom right; SR - straight right; SL - straight left; RSh - right side to the head; RSt - right side to the thigh

For the last subgroup of the third category $(74 \mathrm{~kg})$ comparing the indicators between the groups (control and experimental) showed significantly higher results for the experimental group $(p \leq 0.05)$.

All indicators were significant and reliable at $(p \leq 0.05)$ for the strokes. For the straight right $-15.3 \%$, straight left $41.5 \%$, and bottom-right blow $-30.3 \%$ at $(p \leq 0.05)$.

The index in the knee-lower right-hand stroke is higher, respectively $37.1 \% \mathrm{~W} / \mathrm{kg}$ at $(\mathrm{p} \leq 0.05)$ and in the straight right stroke $-25.2 \%$ at $(p \leq 0.05)$ and straight left $-33.7 \%$ at $(p \leq 0.05)$.

But the shin stroke is also a statistically significant indicator right side to the head $-66.6 \%$ at $(p \leq 0.05)$ and right side to the thigh $-23.8 \%$ at $(p \leq 0.05)$.

Table. 4 compares the performance of the impact technique between the kickboxer control group at the pre-basic weight training stage. Analysing the impact technique for the control group, the indicators had some differences. For the control group, reliability was found in four indicators.
When, to a certain extent, certain values of growth, they came from the definition of indicators of the straight right punch $6.89 \%(p \leq 0.05)$ - the second category (70 kg).

The straight left stroke, which was higher but not reliable, ranged from $2.5-5 \%$ in favor (1st category, $67 \mathrm{~kg})(p>0.05)$. For shin strokes there were following results: straight right $18.7-50 \%(p \leq 0.05)$ right-sided stroke - 19.8-23.8\% $(p \leq 0.05)$ and foot strokes: straight right $-25.2 \%(p \leq 0.05)$, left-sided $34.8 \%(p \leq 0.05)$ (Ist category, $67 \mathrm{~kg})$.

However, for one stroke, the right bottom knee stroke 4.44-6.81\% with positive shifts for the results of most athletes (representatives of different weight categories) no reliable level was reached $(p>0.05)$. This indicates the low efficiency of the proposed methodological approach used in the standardized (traditional program).

Thus, it is confirmed that a standardized program of technical readiness for kickboxers at the stage of preliminary basic training does not lead to positive changes in athletes' 
Table 3. The ratio of the impact of kickboxers III category $(74 \mathrm{~kg})$ of the control and experimental groups $(\mathrm{M} \pm \mathrm{m})$

\begin{tabular}{clccc}
\hline Indicator & Execution of blows & $\begin{array}{c}\text { III (74 kg) }(\mathbf{C G}) \\
(\mathbf{n}=\mathbf{1 0})\end{array}$ & $\begin{array}{c}\text { III }(\mathbf{7 4} \mathbf{~ k g})(\mathrm{EG}) \\
(\mathbf{n}=\mathbf{1 0})\end{array}$ & $\mathbf{p}$ \\
\hline & arm punch (SR)) & $0.42 \pm 0.04$ & $0.49 \pm 0.06$ & $\mathrm{p} \leq 0.05$ \\
& arm punch (LS) & $0.40 \pm 0.03$ & $0.61 \pm 0.14$ & $\mathrm{p} \leq 0.05$ \\
& arm punch (BR) & $0.42 \pm 0.04$ & $0.57 \pm 0.10$ & $\mathrm{p} \leq 0.05$ \\
& knee strike (BR) & $0.46 \pm 0.07$ & $0.67 \pm 0.14$ & $\mathrm{p} \leq 0.05$ \\
$\overrightarrow{3}$ & foot kick (SR) & $0.38 \pm 0.03$ & $0.49 \pm 0.07$ & $\mathrm{p} \leq 0.05$ \\
& foot kick (SL) & $0.32 \pm 0.02$ & $0.45 \pm 0.05$ & $\mathrm{p} \leq 0.05$ \\
& foot kick (RSh) & $0.21 \pm 0.03$ & $0.35 \pm 0.04$ & $\mathrm{p} \leq 0.05$ \\
& foot kick (RSt) & $0.48 \pm 0.06$ & $0.62 \pm 0.15$ & $\mathrm{p} \leq 0.05$ \\
\hline
\end{tabular}

Note: CG - control group; EG - experimental group

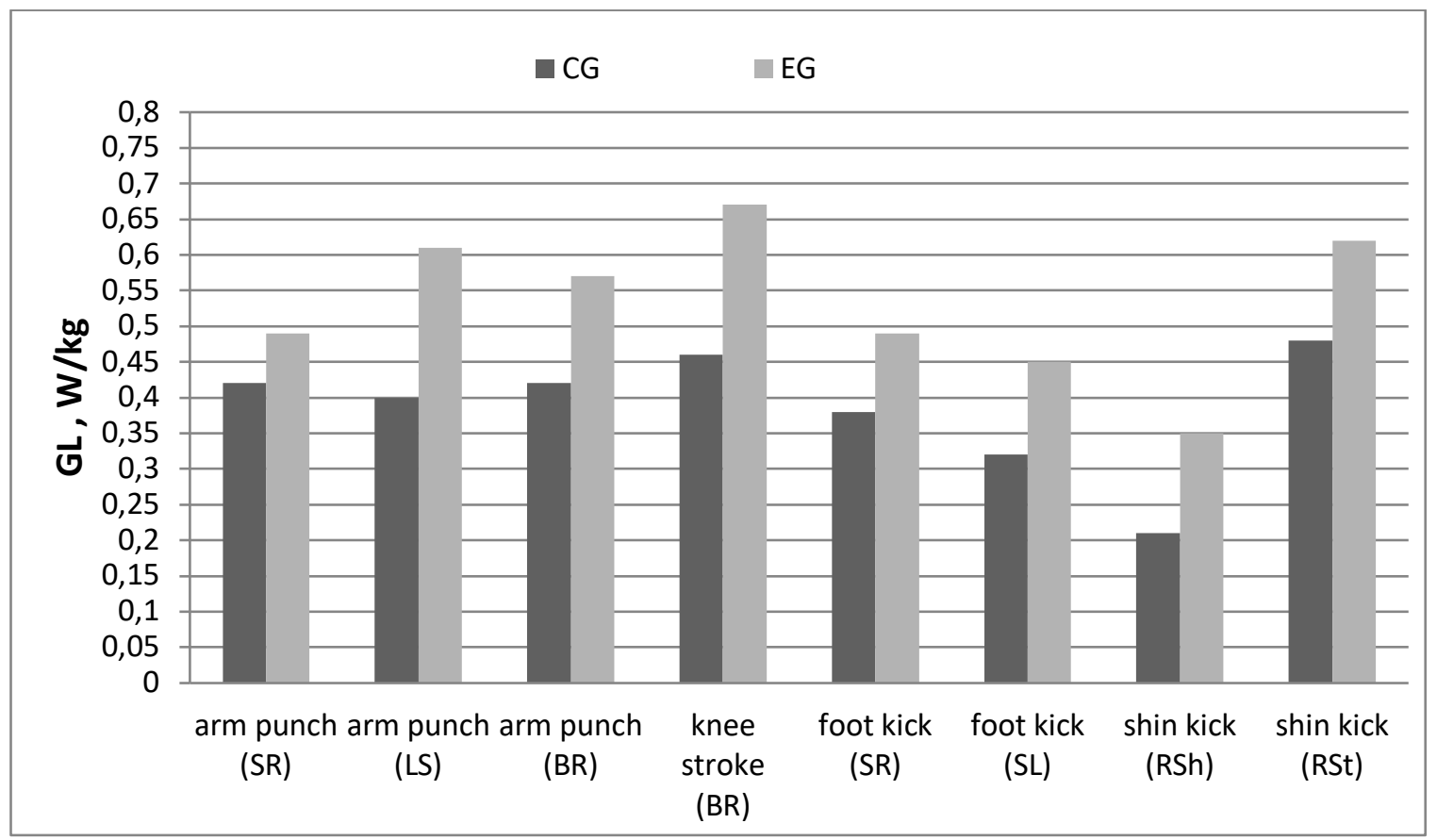

Fig. 3. The impact techniques of the kickboxers of the third category $(74 \mathrm{~kg})$ : SR - straight right; LS - left side; BR bottom right; SR - straight right; SL - straight left; RSh - right side to the head; RSt - right side to the thigh

readiness for various technical actions. The lower results of the kickboxers of the control group of the third category $(74 \mathrm{~kg})$ in technical actions are associated with a complex structure of movements $(p \leq 0.05)$ and their own endurance. This means that athletes performed the work with maximum force in the process of execution but could not ensure the effectiveness of technical action. Probably the lack of a sufficient level of technical preparedness made it impossible to carry out the stroke effectively.

According to the ratio of impact techniques between the experimental group at the stage of preliminary basic training, taking into account the weight categories, although they are at a higher level than the control group, but also have some differences. Analyzing the hands impact techniques (bottom right punch) although it was not significant, but reliable at $7.2 \%, p \leq 0.05$, II category $(70 \mathrm{~kg})$, by side stroke criteria -
6.7\% ( $p \leq 0.05)$ and bottom stroke 5.8-13.0\%. bottom-right knee stroke $-9.37 \%(p>0.05)$ (III category $(74 \mathrm{~kg}))$.

The other five indicators were statistically significant in favor of a particular weight category. Yes, reliable indicators for the 1st category $(67 \mathrm{~kg})(p \leq 0.05)$ right-sided to the head and right-sided stroke to the hip which was within 25.7$33.3 \%(p \leq 0.05)$. According to the latest blow, which is the highest in the group of the II category $(70 \mathrm{~kg})$, the straight right is $31.0 \%$ and the straight left is $36.5 \%(p \leq 0.05)$.

As a result of technical actions for I (67 kg) and II $(70 \mathrm{~kg})$ categories, we associate them with higher coordination and adaptation processes. According to them, we see possible positive trends in the continuing of training influences under the experimental program. However, the representatives of the experimental group showed an increase in performance for all technical activities, achieved higher shock gains $(p \leq 0.05)$. 
Hutsul, N., Rykhal, V., Okopnyy, A., \& Vovk, I. (2020). Comparative Analysis of the Kickboxers' Impact Techniques Indicators at the Preliminary Basic Training Stage Taking Into Account the Weight Categories

Table 4. The ratio of the impact of kickboxers at the stage of preliminary basic training considering weight categories

\begin{tabular}{|c|c|c|c|c|c|c|c|}
\hline Indicator & $\begin{array}{c}\text { Execution of } \\
\text { blows }\end{array}$ & Groups & $\begin{array}{c}\text { I (67 kg) } \\
(\mathrm{n}=10)\end{array}$ & p & $\begin{array}{l}\text { II (70 kg) } \\
(\mathrm{n}=10)\end{array}$ & $\mathbf{p}$ & $\begin{array}{l}\text { III (74 kg) } \\
\quad(\mathrm{n}=10)\end{array}$ \\
\hline \multirow{16}{*}{ 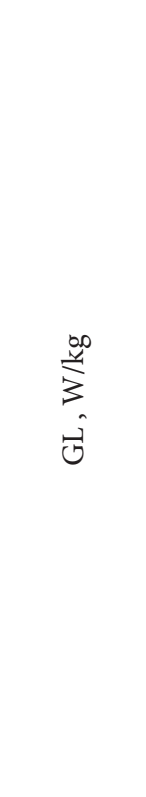 } & \multirow[t]{2}{*}{ arm punch (SR) } & CG & $0.44 \pm 0.05$ & $\mathrm{p} \leq 0.05$ & $0.45 \pm 0.05$ & $\mathrm{p}>0.05$ & $0.42 \pm 0.04$ \\
\hline & & EG & $0.51 \pm 0.09$ & $\mathrm{p} \leq 0.05$ & $0.54 \pm 0.08$ & $\mathrm{p}>0.05$ & $0.49 \pm 0.06$ \\
\hline & \multirow[t]{2}{*}{ arm punch (LS) } & CG & $0.41 \pm 0.03$ & $\mathrm{p}>0.05$ & $0.39 \pm 0.03$ & $\mathrm{p} \leq 0.05$ & $0.40 \pm 0.03$ \\
\hline & & EG & $0.57 \pm 0.12$ & $\mathrm{p} \leq 0.05$ & $0.58 \pm 0.16$ & $\mathrm{p} \leq 0.05$ & $0.61 \pm 0.14$ \\
\hline & \multirow[t]{2}{*}{ arm punch (BR) } & CG & $0.44 \pm 0.04$ & $\mathrm{p}>0.05$ & $0.43 \pm 0.04$ & $\mathrm{p}>0.05$ & $0.42 \pm 0.04$ \\
\hline & & EG & $0.53 \pm 0.10$ & $\mathrm{p}>0.05$ & $0.50 \pm 0.08$ & $\mathrm{p} \leq 0.05$ & $0.57 \pm 0.10$ \\
\hline & \multirow[t]{2}{*}{ knee strike (BR) } & CG & $0.47 \pm 0.06$ & $p>0.05$ & $0.44 \pm 0.06$ & $\mathrm{p} \leq 0.05$ & $0.46 \pm 0.07$ \\
\hline & & EG & $0.61 \pm 0.14$ & $\mathrm{p} \leq 0.05$ & $0.63 \pm 0.12$ & $\mathrm{p} \leq 0.05$ & $0.67 \pm 0.14$ \\
\hline & \multirow[t]{2}{*}{ foot kick (SR) } & CG & $0.49 \pm 0.08$ & $\mathrm{p} \leq 0.05$ & $0.50 \pm 0.11$ & $\mathrm{p}>0.05$ & $0.38 \pm 0.03$ \\
\hline & & EG & $0.67 \pm 0.16$ & $\mathrm{p} \leq 0.05$ & $0.71 \pm 0.17$ & $\mathrm{p}>0.05$ & $0.49 \pm 0.07$ \\
\hline & \multirow[t]{2}{*}{ foot kick (SL) } & CG & $0.45 \pm 0.03$ & $\mathrm{p} \leq 0.05$ & $0.46 \pm 0.03$ & $\mathrm{p}>0.05$ & $0.32 \pm 0.02$ \\
\hline & & $\mathrm{EG}$ & $0.65 \pm 0.15$ & $\mathrm{p} \leq 0.05$ & $0.68 \pm 0.16$ & $\mathrm{p} \leq 0.05$ & $0.45 \pm 0.05$ \\
\hline & \multirow[t]{2}{*}{ foot kick (RSh) } & CG & $0.35 \pm 0.02$ & $\mathrm{p}>0.05$ & $0.29 \pm 0.02$ & $\mathrm{p}>0.05$ & $0.21 \pm 0.03$ \\
\hline & & $\mathrm{EG}$ & $0.49 \pm 0.08$ & $\mathrm{p} \leq 0.05$ & $0.50 \pm 0.10$ & $\mathrm{p}>0.05$ & $0.35 \pm 0.04$ \\
\hline & \multirow[t]{2}{*}{ foot kick (RSt) } & CG & $0.61 \pm 0.014$ & $\mathrm{p}>0.05$ & $0.50 \pm 0.08$ & $\mathrm{p}>0.05$ & $0.48 \pm 0.06$ \\
\hline & & EG & $0.79 \pm 0.18$ & $\mathrm{p}>0.05$ & $0.61 \pm 0.11$ & $\mathrm{p} \leq 0.05$ & $0.62 \pm 0.15$ \\
\hline
\end{tabular}

Note: CG - control group; EG - experimental group

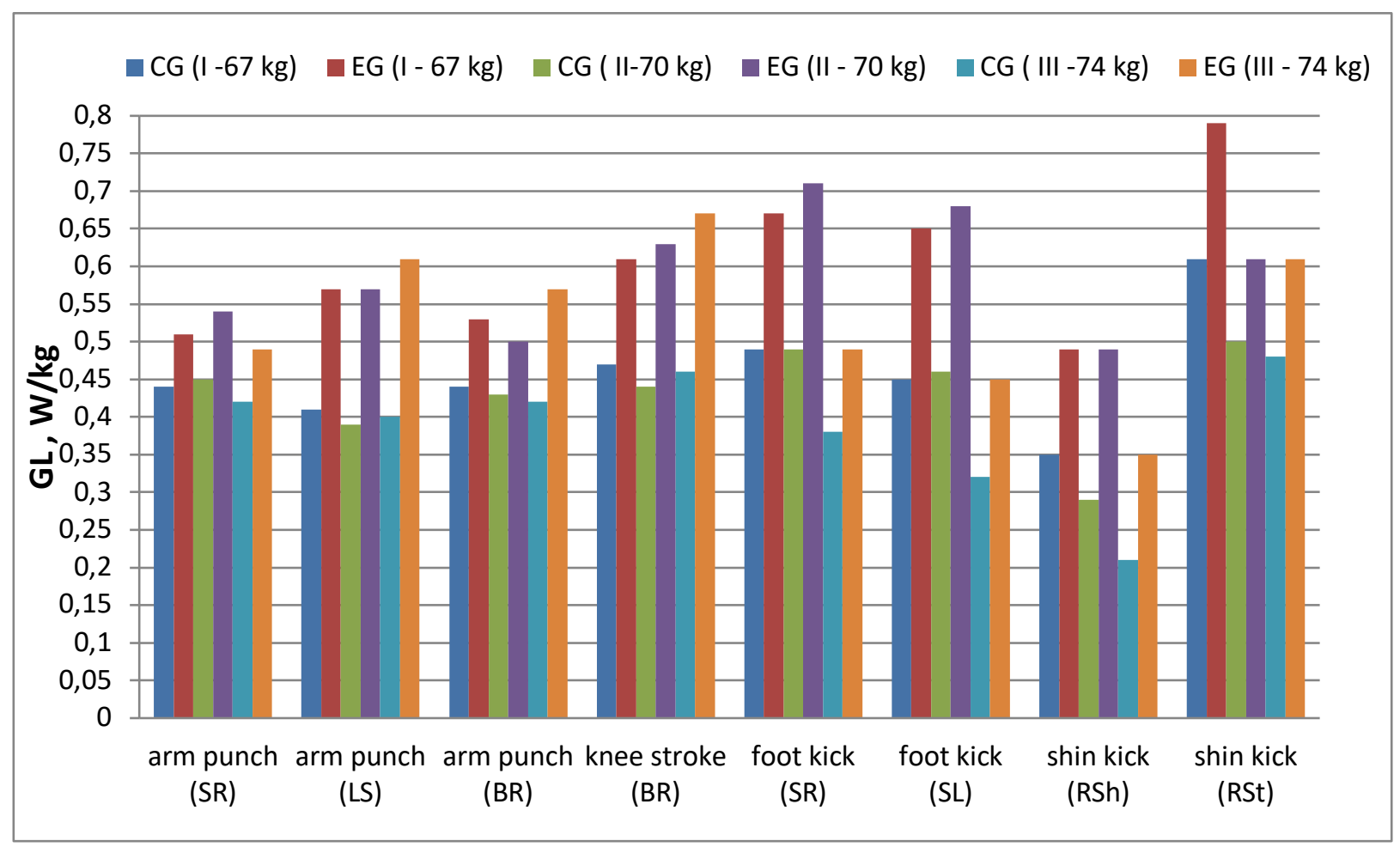

Fig. 4. Impact techniques indicators taking into account the weight categories: SR - straight right; LS - left side; BR - bottomright; SR - straight right; SL - straight left; RSh - right side to the head; RSt - right side to the thigh

\section{Discussion}

The work compares the impact technique of kickboxers on the stage of preliminary basic training, considering the weight categories for further improvement of competitive activity. The results are complementary to those of kickboxing scientists, as Skyrta and Khatsaiuk (2014), Pityn, Okopnyy, Tyravska, Hutsul, and Ilnytsky (2017) and other martial karate - Sayenko (2010).

The obtained data complements the one gathered by Skyrta and Khatsaiuk (2014), Pityn et al. (2017), Zadorozhna, Okopnyy, Hutsul, Kotelnyk, Grashchenkova, Perederiy, 
Pityn, and Svistelnyk (2019) that due to the effective technical actions used in the competitive battle led to its successful outcome.

The data on the improvement of motor technique, which is one of the crucial components in the realization of the motor potential of the athlete, have been supplemented (Platonov, 2004; Kashuba \& Lytvynenko, 2010).

Data on improving the quality of technical training in martial arts have been supplemented (Boychenko, 2008; Stewart, 2011; Agafonov, 2013).

The results of the technical analysis of motor actions indicate the data Gartland, Malik, and Lovell (2005), Gerasimov (2014) about the success of competitive activities. The results confirm the conclusions Skyrta and Khatsaiuk (2014); Hutsul and Rykhal (2020) on the need to expand the arsenal of technical means, eliminate technical shortcomings in the movement (when striking the upper and lower extremities, protection and economical execution of movements and increase the speed of movements).

The study specified the data Romanov (2014), Hölbling, Preuschl, Hassmann, and Baca (2016), Hutsul et al. (2019) on the features of coordinated motor action on the effectiveness of the kickboxer technique.

The results show that a successful fight depends on the level of technical training in martial arts. This confirms the conclusion of researchers that the technique of sports exercises is closely related to competitive activities that determine the achievement of the highest sports results (Pat, 2002; Khatsaiuk \& Karataieva, 2008; Morgunov, Sagaydak, \& Dorofeeva, 2009).

As a result of the analysis it is established that time for performance of effective shock action in kickboxing is an informative indicator of technical readiness of kickboxers of various qualification during competitive activity. These data complement the results of the study by Ouergui, Hssin, Franchini, Gmada, and Bouhlel (2013), Gerasimov (2014), Skyrta and Khatsaiuk (2014) and indicate the features of the technical training of kickboxers in the competitive process. Data on the use of the chronodynamometry method to determine the dynamics of technical readiness of fighters have been supplemented (Yaremko, 2001; Savchyn, 2003; Saienko, 2010).

\section{Conclusions}

The study of existing research has revealed that the analysis of motor performance techniques of kickboxers can be a component of training to improve the efficiency of the training process and the effectiveness of competitive activities.

The analysis of the special literature allowed to determine the most frequently performed percussion techniques in oriental martial arts.

The results obtained after the experiment indicate that the indicators of technical motor actions of kickboxers in the experimental group are significantly higher $(\mathrm{p} \leq 0.05)$ than in the control group. A detailed analysis of the technique of percussion among kickboxers allowed to establish the difference in technical training between athletes of the experimental and control groups, taking into account weight categories during the performance of eight strokes for the first category $(67 \mathrm{~kg})$ were in the range of $14.7-36.3 \%$ (in the second category, $70 \mathrm{~kg})-15.0-51.2 \%$ and III category $(74 \mathrm{~kg})-15.3-66.6 \%$ in favor of the experimental group.

\section{Conflict of interests}

The authors declare no conflict of interest.

\section{References}

Yaremko, M.O. (2001). Vdoskonalennia shvydkisno-sylovykh yakostei $v$ udarnykh pryiomakh kikbokseriv na etapi poperednoi bazovoi pidhotovky [dysertatsiia]. Lviv: Lviv derzh in-t fiz. Kultury, 226 s. (in Ukrainian)

Skyrta, O.S., Horbenko V.P., Khatsaiuk, O.V., \& Piniker, O.S. (2014). Doslidzhennia zavadostiikosti kikbokseriv u rozdili oriiental na etapi spetsializovanoi bazovoi pidhotovky. Sportyvnyi visnyk Prydniprovia, (3), 110-117.

Buse, G.J., \& Santana, J.C. (2008). Conditioning strategies for competitive kickboxing. Strength \& Conditioning Journal, 30(4), 42-48. https://doi.org/10.1519/SSC.0b013e31817f19cd

Platonov, V.N. (2004). Sistema podgotovki sportsmenov $v$ olimpiyskom sporte. Obshchaya teoriya i ee prakticheskiye prilozheniya. K.: Olimpiyskaya literatura, 808. (in Ukrainian)

Platonov, V.N. (1997). Obshchaia teoryia podhotovky sportsmenov v olympyiskom sporte. K.: Olympyiskaia lyteratura, 583. (in Ukrainian)

Romanov, Yu.N. (2003). Taktycheskaia podhotovka v kykboksynhe: uchebnoe posobye. Cheliabynsk: YuUrHU, 75. (in Russian)

Skyrta, O.S., \& Khatsaiuk, O.V. (2014). Analiz udarnoi tekhniky kikbokseriv WPKA $\mathrm{v}$ rozdili oriiental $\mathrm{z}$ vykorystanniam novitnikh tekhnolohii. Aktualni problemy rozvytku tradytsiinykh i skhidnykh yedynoborstv. Zb. tez dop. VIII Mizhnar. elektron. nauk.-metod. konf. Kharkiv: Akademiia VV MVS Ukrainy. (in Ukrainian)

Hutsul, N.Z., Skyrta, O.S., \& Rykhal, V.I. (2019). Zistavlennia pokaznykiv tekhniko-taktychnykh dii kvalifikovanykh kikbokseriv na riznykh etapakh bahatorichnoi pidhotovky. Naukovyi chasopys Natsionalnoho pedahohichnoho universytetu imeni M.P.Drahomanova. Seriia № 15. Naukovo-pedahohichni problemy fizychnoi kultury (fizychna kultura i sport): [zb. nauk.pr.]. Kyiv; 5 K (113)19, 94-101

Booth, G. (2006). Training for real. Australian taekwondo magazine, 15(2), 20.

Kiatbusaba, P. (2013). Lanna Muay Thai Boxing Camp. Muay Thai Boxing.

Stewart, A. (2011). The Boxer's "Pugilistic-Present" Ethnographic Notes Towards a Cultural History of Amateur and Professional Boxingin England. Sportin History, 31(4), 464-486. https://doi.org/10.1080/17460263.2011.645337

Ostianov, V.N., \& Haidamak, I.I. (2001). Boks (obuchenye y trenyrovka). Kyiv: Olimpiiska literatura; 237 s. (in Ukrainian)

Bakulev, S.E., Nazarenko, M.V., \& Momot, D.A. (2007). Osnovy podgotovki v kikboksinge: ucheb. posobiye. SPb.: Feder. agentstvo po fiz. kulture i sportu. 204 s (in Russian)

Pat, O'Keeffe (2002). Kick boxing - a framework for success. Summersdale Publishers Ltd. Chichester. 160 p.

Ouergui, I., Hssin, N., Haddad, M., Franchini, E., Behm, D.G., Wong, D.P., Gmada, N., \& Bouhlel, E. (2014). Timemotion analysis of elite male kickboxing competition. J Strength Cond Res, 28(12), 3537-3543. https://doi.org/10.1519/JSC.0000000000000579 
Hutsul, N., Rykhal, V., Okopnyy, A., \& Vovk, I. (2020). Comparative Analysis of the Kickboxers' Impact Techniques Indicators at the Preliminary Basic Training Stage Taking Into Account the Weight Categories

Savchyn, M.P. (2003). Trenovanist boksera ta yii diahnostyka. Kyiv: Nora-print. 220 s. (in Ukrainian)

Pityn, M., Okopnyy, A., Tyravska, O., Hutsul, N., \& Ilnytsky, I. (2017). Dynamic of indexes of technical and tactical actions of qualified kickboxer individual fighting style. Journal of Physical Education and Sport (JPES), 17(s3), 1024-1030. https://doi.org/10.7752/jpes.2017.s3157

Gerasimov, M. V. (2014). Technical-tactical fitness indices of elite kickboxers in "point fighting" division. Teoriya $i$ Praktika Fizicheskoy Kultury, (6), 77-79.

Hutsul, N., \& Rykhal, V. (2020). Analiz zmahalnoi diialnosti kikbokseriv na etapi poperednoi bazovoi pidhotovky. V: Arziutov HM, redaktor. Naukovyi chasopys Nats. ped. un-tu im. M. P. Drahomanova. Seriia 15, Naukovopedahohichni problemy fizychnoi kultury (fizychna kultura i sport). [zb. nauk.pr.]. Kyiv; $3 \mathrm{~K}(123) 20,125-130$. (in Ukrainian)

Saienko, V.H. (2010). Shvydkisni ta sylovi parametry udariv rukamy u vysokokvalifikovanykh karatystiv. Moloda sportyvna nauka Ukrainy: Zb. nauk. prats z haluzi fizychnoi kultury ta sportu, 1, 278-282. (in Ukrainian)

Prystupa, E., Okopnyy, A., Hutsul, N., Khimenes, Kh., Kotelnyk, A., Hryb, I., \& Pityn, M. (2019). Development of special physical qualities skilled kickboxers various style of competitive activity. Journal of Physical Education and Sport, 19(s2), 273-280. https://doi.org/10.7752/jpes.2019.s2041

Zadorozhna, O., Okopnyy, A., Hutsul, N., Kotelnyk, A., Grashchenkova, Z., Perederiy, A., Pityn, M., \& Svistelnyk, I. (2019). Improving kickboxers' special physical preparedness which accounts for their individual tactical style and technical skills. Journal of Physical Education and Sport (JPES), 19(2), 1173-1179.

https://doi.org/10.7752/jpes.2019.02170

Kashuba, V., \& Lytvynenko, Yu. (2010). Suchasni biomekhanichni erhohenni zasoby v sporti. Sportyvnyi visnyk Prydniprovia, (3), 4-6 (in Ukrainian)

Boychenko, N. V. (2008). Ways of improving technical preparation of combat sportsmen. Pedagogika, psihologia ta mediko-biologicni problemi fizicnogo vihovanna i sportu, (2), 19-21.

Agafonov, A.I. (2013). Biomekhanicheskiy analiz tekhniki udarov nogami kikbokserov razlichnykh kvalifikatsionnykh grupp. Fundamentalnye issledovaniya, 10 (chast 9), 2031-2035.

http://www.fundamental-research.ru/ru/article/ view?id=32582

Gartland, S. M., Malik, H.A., \& Lovell, M.E. (2005). A prospective study of injuries sustained during competitive Muay Thai kickboxing. Clinical Journal of Sport Medicine, (15), 34-36. https://doi.org/10.1097/00042752-200501000-00007

Romanov, Yu.N. (2014). Osobennosti dolgovremennoy adaptatsii kikbokserov $v$ sisteme integralnoy podgotovki : avtoref. dis. na polucheniye nauch. stepeni doktora biologicheskikh nauk: spets. 03.03.01 "Fiziologiya". Chelyabinsk, 46. (in Russian)

Hölbling, D., Preuschl, E., Hassmann, M., \& Baca, A. (2016). Kinematic analysis of the double side kick in pointfighting, kickboxing. Journal of sports sciences, 35(4), 1-8. https://doi.org/10.1080/02640414.2016.1164333

Khatsaiuk, O.V., \& Karataieva, D.O. (2008). Udoskonalennia tekhniky rukopashnoho boiu pravookhorontsiv MVS Ukrainy iz vykorystanniam suchasnykh tekhnichnykh zasobiv navchannia. (Shyfr "Model-RB", nomer derzhavnoi reiestratsii 0108U007536). Nauk. Doslid. Rob. Kharkiv: AVV MVSU.

Morgunov, A.A., Sagaydak, S.N., \& Dorofeeva, T.I. (2009). Influence of operative correction on technical tactical actions at kickboxer. Pedagogics, psychology, medicalbiological problems of physical training and sports, 11, 60-68.

Ouergui, I., Hssin, N., Franchini, E., Gmada, N., \& Bouhlel, E. (2013). Technical and tactical analysis of high level kickboxing matches. International Journal of Performance Analysis in Sport, 13(2), 294-309.

https://doi.org/10.1080/24748668.2013.11868649

\title{
ПОРІВНЯЛЬНИЙ АНАЛІЗ ПОКАЗНИКІВ ТЕХНІКИ УДАРНИХ ДІЙ КІКБОКСЕРІВ НА ЕТАПІ ПОПЕРЕДНЬОЇ БАЗОВОЇ ПІДГОТОВКИ 3 УРАХУВАННЯМ ВАГОВИХ КАТЕГОРІЙ
}

\author{
Наталія Гуцул $^{1 \mathrm{ABCD}}$, Володимир Рихаль ${ }^{2 \mathrm{ABCD}}$, Андрій Окопний ${ }^{2 \mathrm{ABCD}}$, Ігор Вовк ${ }^{3 \mathrm{ABCD}}$ \\ ${ }^{1}$ Українська академія друкарств, \\ ${ }^{2}$ Львівський державний університет фізичної культури імені Івана Боберського, \\ ${ }^{3}$ Львівський національний аграрний університет
}

Авторський вклад: А - дизайн дослідження; В - збір даних; C - статаналіз; D - підготовка рукопису; Е - збір коштів

Реферат. Стаття: 8 с., 4 табл., 4 рис., 31 джерело

Мета дослідження - провести порівняльний аналіз показників техніки ударних дій кікбоксерів експериментальної та контрольної групи на етапі попередньої базової підготовки з урахуванням вагових категорій.

Матеріали і методи. У педагогічному дослідженні прийняли участь 60 кікбоксерів, які знаходились на етапі попередньої базової підготовки. Були створені дві одно- рідні групи, експериментальна група (30 чоловік по 10 в кожному розряді, I (67 кг), II (70 кг) та III (74 кг) та контрольна група (30 чоловік по 10 в кожному розряді, I (67 кг), II (70 кг) та III (74 кг).

Результати. За співвідношенням кількісних показників техніки ударних дій між групами (контрольної та експериментальної) визначають ефективність технічних 
дій кікбоксерів на етапі попередньої базової підготовки з урахуванням вагових категорій, де за всіма показниками експериментальна група достовірно перевищила $(p \leq 0,05)$ контрольну групу.

Висновки. Вивчення існуючих досліджень дозволило констатувати, що аналіз техніки виконання рухових дій у кікбоксерів може бути компонентом підготовки 3 метою підвищення ефективності тренувального процесу та результативності змагальної діяльності.

Проведений аналіз спеціальної літератури дозволив визначити найчастіше виконувані ударні технічні прийоми у східних єдиноборствах.

Результати, що були отримані унаслідок проведення експерименту, свідчать про те, що показники технічних рухових дій кікбоксерів експериментальної групи достовірно вищі $(p \leq 0,05)$ ніж в контрольній групі. Детальний аналіз техніки ударних дій серед кікбоксерів дозволив встановити різницю в технічній підготовленості між спортсменами експериментальної та контрольної групи з урахуванням вагових категорій під час виконання восьми ударів для I розряду (67 кг) знаходились в межах 14,7-36,3\%, в II розряді (70 кг) - 15,0-51,2\% та III розряді (74 кг) - 15,3-66,6\% на користь експериментальної групи.

Ключові слова: техніка, удари, кікбоксери, масові розряди, етап попередньої базової підготовки.

\section{Information about the authors:}

Hutsul Natalia: umbanathalie88@gmail.com; https://orcid.org/0000-0002-6080-2369; Ukrainian Academy of Printing, Pid Holoskom St, 19, Lviv, Lviv Oblast, 79020, Ukraine.

Rykhal Volodymyr: rykhal8888@gmail.com; https://orcid.org/0000-0002-1670-0066; Lviv State University of Physical Culture named after Ivan Boberskyi, Tadeusha Kostyushka St, 11, Lviv, Lviv Oblast, 79007, Ukraine.

Okopnyy Andriy: okopnuy@rambler.ru; https://orcid.org/0000-0001-5277-7952; Lviv State University of Physical Culture named after Ivan Boberskyi, Tadeusha Kostyushka St, 11, Lviv, Lviv Oblast, 79007, Ukraine.

Vovk Ihor: igorvasylovych@gmail.com; https://orcid.org/0000-0001-6075-6094; Lviv National Agrarian University, Volodymyra Velykoho St, 1, Dubliany, Lviv Oblast, 80381, Ukraine.

Cite this article as: Hutsul, N., Rykhal, V., Okopnyy, A., \& Vovk, I. (2020). Comparative Analysis of the Kickboxers' Impact Techniques Indicators at the Preliminary Basic Training Stage Taking Into Account the Weight Categories. Teoriâ ta Metodika Fizičnogo Vihovannâ, 20(3), 182-190. https://doi.org/10.17309/tmfv.2020.3.08

Received: 12.07.2020. Accepted: 20.09.2020. Published: 25.09.2020

This work is licensed under a Creative Commons Attribution 4.0 International License (http://creativecommons.org/licenses/by/4.0). 